\title{
A year in an ant's life: Opportunism and seasonal variation in the foraging ecology of Aphaenogaster senilis ${ }^{1}$
}

\author{
Stephane $\mathrm{CAUT}^{2},{ }^{3}$, Ángel BARROSO ${ }^{3}, \mathrm{Xim}_{\mathrm{CERDÁ}} \&$ Fernando AMOR, Estación Biológica de Doñana, \\ Avenida Americo Vespucio s/n, 41092 Sevilla, Spain, e-mail: stephanecaut@gmail.com \\ Raphaël R. BOULAY, Estación Biológica de Doñana, Avenida Americo Vespucio s/n, 41092 Sevilla, Spain, \\ and Departamento de Zoología, Universidad de Granada, Campus Fuentenueva, 18010 Granada, Spain.
}

\begin{abstract}
Ants are important consumers in most terrestrial ecosystems. They show a great diversity of diets and foraging strategies. Here, we analyzed how circannual variation in resource use by the Mediterranean species Aphaenogaster senilis is related to colony life cycle and resource availability. In southwestern Spain, this species is active almost year-round, but foraging intensity decreases 10 -fold between March and November, following larval production. In the summer, ants refrain from foraging at midday to avoid high temperatures. We hypothesized that diet and foraging plasticity could also explain the ecological success of this species. There are several techniques for assessing the diet of ants. Combining isotope analyses with conventional methods can provide better taxonomic resolution of resource utilization. Using a combination of classic and isotopic analyses, we found that 1) the proportion of plant and animal-derived items collected by foragers did not vary significantly from March to November, and 2) isotope analyses indicated a decrease in the trophic level of A. senilis between June and September, suggesting a difference between collected material and items assimilated. Interestingly, most animal prey were collected by individual ants, and many were retrieved alive. Therefore, A. senilis is not only a scavenger, but also a non-negligible predator, particularly of aphids. The abundance of the most common animal-derived items in the diet was proportional to their abundance in the study area. We conclude that $A$. senilis is an opportunistic species that is able to feed on a variety of resources, which may be key to its ecological success.

Keywords: ant, diet item, Formicidae, stable isotope, trophic ecology.
\end{abstract}

Résumé: Les fourmis sont des consommateurs importants dans la plupart des écosystèmes terrestres. Elles montrent une grande diversité de stratégies de recherche de nourriture et de régimes alimentaires. Nous avons analysé comment la variation circannuelle de l'utilisation des ressources par l'espèce méditerranéenne Aphaenogaster senilis est reliée au cycle de vie de la colonie et à la disponibilité des ressources. Au sud-ouest de l'Espagne, cette espèce est active presque toute l'année, mais l'intensité de sa quête alimentaire est réduite d'un facteur 10 entre mars et novembre après la production de larves. En été, les fourmis s'abstiennent de fourrager au milieu de la journée pour éviter les températures trop élevées. Nous avons formulé l'hypothèse que la plasticité du régime et de la quête alimentaires pourrait aussi expliquer le succès écologique de cette espèce. Il y a plusieurs techniques pour déterminer le régime alimentaire des fourmis; la combinaison d'analyses isotopiques et de méthodes classiques peut fournir une meilleure résolution taxonomique de l'utilisation des ressources. En combinant des analyses classiques et isotopiques, nous avons trouvé: 1) que la proportion de plantes et d'éléments d'origine animale récoltés par les fourmis fourrageuses ne variait pas significativement entre mars et novembre; et 2) les analyses isotopiques ont indiqué une diminution du niveau trophique de A. senilis entre juin et septembre, suggérant qu'il y avait une différence entre ce qui était récolté et ce qui était assimilé. Un résultat intéressant est que la plupart des proies animales ont été récoltées par des fourmis individuelles et plusieurs ont été retrouvées vivantes. Ainsi, A. senilis n'est pas seulement détritivore, mais est également un prédateur non négligeable, particulièrement d'aphidés. L'abondance des éléments d'origine animale les plus communs dans le régime alimentaire était proportionnelle à leur abondance dans l'aire d'étude. Nous concluons donc que $A$. senilis est une espèce opportuniste capable de se nourrir d'une variété de ressources, ceci étant peut-être la clé de son succès écologique.

Mots-clés : composante du régime alimentaire, écologie trophique, Formicidae, fourmi, isotope stable.

Nomenclature: Gomez \& Espalader, online; Monnin et al., 2013.

\section{Introduction}

Gathering food for survival and reproduction is an essential activity for most animals. Foraging is costly, because it requires time and energy that cannot be allocated to other activities and because it increases the risk of predation and parasite exposure. As a consequence, animals face behavioural trade-offs to which they are expected to respond by optimizing when, where, and on what kind of food they forage (Stephens \& Krebs, 1986). In recent decades, numerous experimental and theoretical studies have addressed important questions regarding the evolution of animal foraging behaviour (Stephens, Brown \& Ydenberg, 2007). Yet, basic studies on the feeding habits of wild animals are still needed, particularly for non-specialist 
consumers that may vary their food intake as a function of environmental conditions.

Ants show a great diversity of foraging strategies, including consumption of different resource types and differing levels of cooperation during food collection (Hölldobler \& Wilson, 1990). Because ants are abundant in most terrestrial habitats, their foraging decisions may have important consequences at the ecosystem level. Ant foraging activity patterns may vary both on spatial and temporal (seasonal and daily) scales, depending on environmental conditions (Cook et al., 2011). For example, temperature, humidity, and light intensity are abiotic factors that limit or trigger ant foraging activity (Cerdá, Retana \& Cros, 1998a; Chong \& Lee, 2009; Narendra, Reid \& Hemmi, 2010; Amor et al., 2011; van Oudenhove et al., 2012). Moreover, biotic factors such as colony composition (Judd, 2005; Abril, Oliveras \& Gómez, 2007; Dussutour \& Simpson, 2009), interspecific competition (Carroll \& Janzen, 1973), resource availability (Briese \& Macauley, 1980), and the presence of predators and parasites (Orr \& Seike, 1998) determine both foraging behaviour and the quality of collected resources.

So far, most studies have analyzed ant diet using direct observations of retrieved food items. Some species show a clear consistency in food choice that is independent of temporal and spatial variation in food source abundance. This is the case for many specialist hunters that are behaviourally and morphologically adapted to capture a certain kind of prey (e.g., Hölldobler, 1982; Dejean et al., 1999). Other species, in contrast, show remarkable variability in food source utilization. Temporal dietary changes may result from important plasticity that enables opportunistic ants to adjust their feeding choices so as to consume the most abundant and/or profitable items (Mooney \& Tillberg, 2005). However, they may also be due to variations in internal demand stemming from circannual demographic changes. For example, in temperate habitats, interseasonal variation in the number of larvae may affect the relative need for proteins and carbohydrates (Cassill \& Tschinkel, 1999; Judd, 2005; Abril, Oliveras \& Gómez, 2007; Dussutour \& Simpson, 2009; Cook et al., 2011). Furthermore, foragers given access to only a single food type demonstrate a subsequent preference for rare, alternative resources, which helps them maintain a balanced diet (Edwards \& Abraham, 1990; Kay 2002; 2004).

The study of ant trophic ecology is complicated by several aspects of ant life history, including their sociality and caste system. Moreover, only a fraction of the items returned to the nest may be consumed and assimilated, while the remainder may be used for other functions, such as nest construction (Hölldobler \& Wilson, 1990). Stable isotope analysis offers a powerful complementary approach to traditional observational analyses to study animal diet (Kelly, 2000; Caut, Angulo \& Courchamp, 2009). This method is based on the fact that an organism's nitrogen and carbon isotope ratios $\left(\delta^{13} \mathrm{C}\right.$ and $\left.\delta^{15} \mathrm{~N}\right)$ reflect assimilated resources (see Post, 2002 for review). The former typically increases by $3-4 \%$ o for each trophic level, while the latter is useful in distinguishing between different sources of carbon (e.g., $\mathrm{C}_{3}$ versus $\mathrm{C}_{4}$ plants). The use of stable isotopes in ant trophic ecology is still in its infancy when compared to other study systems (Feldhaar, Gebauer \& Blúthgen, 2010). However, such analyses have proved to be useful in identifying spatial and temporal variations in ant trophic position (Blüthgen, Gebauer \& Fiedler, 2003; Mooney \& Tillberg, 2005; Menke et al., 2010; Gibb \& Cunningham, 2011) and in highlighting dietary differences among nestmates (Smith et al., 2008; Smith \& Suarez, 2010). It has been suggested that combining isotope analyses with conventional methods would provide better taxonomic resolution of resource utilization (Caut, Angulo \& Courchamp, 2008). Isotopic interpretations are very helpful in providing indices of food item contributions in a consumer's diet, but they require prior classical diet analyses in order to identify the correct potential resource items by comparing their isotopic values with those of the consumers. Yet, so far we are not aware of any study undertaken on ants that combined isotope analyses with conventional data on food item retrieval.

The ant Aphaenogaster senilis is a common species in the Iberian Peninsula that performs important ecosystem functions, such as the dispersal of many myrmecochorous plants (Espadaler \& Gómez, 1997; Boulay et al., 2005; 2007a; Bas, Oliveras \& Gómez, 2009). Previous studies have shown that the ecological success of this behaviourally subordinate species partly stems from its relative tolerance to high ground temperatures in contrast to dominant, less thermoresistant competitors (e.g., Tapinoma nigerrimum; van Oudenhove et al., 2012). Moreover, A. senilis colonies are able to rapidly mobilize important worker forces through chemical recruitment in order to efficiently retrieve large food items (Cerdá et al., 2009). Here, we hypothesized that diet and foraging plasticity could also explain the ecological success of this species. We first analyzed the ants' foraging rate and daily pattern of activity and predicted that they would vary in relation to larval production and environmental conditions. Second, we analyzed retrieved food items and compared the abundance of the different insect prey that were harvested with their abundance in the study area throughout the year. We expected $A$. senilis trophic opportunism to be evidenced by a strong correlation between a prey's abundance in nature and its retrieval. Finally, we combined classic and isotopic analyses in order to detect circannual variation in nutrient intake.

\section{Methods}

\section{STUDY SITE AND SPECIES}

The study was conducted at La Algaida, near the town of Sanlucar-de-Barrameda, SW Spain (36 $\left.6^{\circ} 1^{\prime} \mathrm{N}, 6^{\circ} 19^{\prime} \mathrm{w}\right)$. The study area consists of a sandy strip approximately $200 \mathrm{~m}$ wide and several kilometres long located between a marshland and a pine forest. The vegetation is composed of grasses and numerous Pistacea lentiscus and Phyllirea angustifolia shrubs.

The climate is Mediterranean with an oceanic influence. Summers are dry and hot, with almost no precipitation from June to August, and the average daily temperature exceeds $25{ }^{\circ} \mathrm{C}$ (the maximum daily temperature exceeds $35{ }^{\circ} \mathrm{C}$ in July). Winters are relatively mild and humid, with most precipitation occurring between October and April. 
Data were collected over a period of $7 \mathrm{y}$, from 2003 to 2009. Climatic data collected at the Jerez-de-la-Frontera airport (about $21 \mathrm{~km}$ away) indicate that the period of 2003-2006 was relatively dry compared to the average, while greater than average precipitation occurred during the last $3 \mathrm{y}$ of the study (Electronic Appendix EA1).

Aphaenogaster senilis is a monogynous and monandrous species ( 1 singly mated queen per colony). Colonies contain between 120 and 3000 monomorphic workers (Boulay et al., 2007b). They form new societies through the fission of adult colonies into 2 or more colonies. Each new colony is headed by a daughter of the mother queen. This mode of colony founding is relatively secure, and the production of only a few queens is sufficient to guarantee the colony's reproductive success. However, mother colonies lose an important fraction of their worker force during each fission event. Therefore, in species with colony fission, female investment includes the production of numerous workers each year. Only large colonies are able to fission, and they only produce a few queens (up to 5) at each fission event, which mostly occur in summer. Males, which are able to fly and disperse over long distances, are produced in large numbers from May to December, with a peak in MayJune (Boulay et al., 2009).

CiRCANNUAL VARIATION IN COLONY PRODUCTIVITY AND FORAGING ACTIVITY

To assess seasonal variation in colony productivity, a total of 65 nests were excavated at La Algaida between December 2002 and November 2009 (range 2-18 nests per month). Each colony was brought to the laboratory so that we could count the workers and weigh total larval fresh biomass.

Aphaenogaster senilis foraging activity was estimated by observing focal nests during 10-min sessions held every hour from sunrise to sunset. During each session, all outgoing and incoming ants were recorded. Among incoming ants, we differentiated between those carrying a food item and those returning without food (this species has lost the capacity of trophallaxis and is not known to consume liquid sugars like plant nectars or aphid honeydew; we therefore assume that all food was carried in the mandibles and not in the crop). Measurements of foraging activity were conducted over $23 \mathrm{~d}$ and on 58 nests between March 2003 and November 2009. Four nests were observed 8 times in 2006, with 1-month intervals between observation days. All the other nests were observed on 1 single day.

\section{ANALYSIS OF RETRIEVED ITEMS}

Circannual variation in the composition of items retrieved by $A$. senilis workers was analyzed using data collected over a total of $10 \mathrm{~d}$ throughout the year 2009 (February to November) and in April 2006. For 3-4 nests per day, all items transported by the ants were collected as foragers were returning during the hourly 10 -min observation sessions. The nests used in this experiment (total $n=37$ ) were different from those used previously to quantify foraging activity and larval production. Each item was preserved in alcohol until its identification in the laboratory. Plant material was identified to the genus or species level. Animal material was identified to the order level. Animal prey length was measured to the nearest millimetre.

In order to estimate variation in the availability of animal prey, 3 sets of 7 pitfall traps (4-cm-wide, 7-cm-deep plastic cups filled with water and soap) were installed along a 50-m transect and run for $24 \mathrm{~h}$ at the same time and in the same area as for the food retrieval analysis. However, the pitfall traps were sufficiently distant from the observed nests to ensure that there was no interference between the 2 samplings. Within sets, pitfall traps were arranged in 2 rhombuses (5-m diagonal) united by 1 of their corners. The biological material collected was pooled by set and kept in $70 \%$ alcohol until further identification and isotopic analyses could take place. Pitfall traps were installed soon after prey collection, on a day with similar weather.

\section{ISOTOPIC ANALYSES}

Isotopic analyses were conducted on 30 samples of A. senilis workers ( 3 per month) collected in pitfall traps throughout the year (April 2006 and February, March, and May to November 2009). In order to reduce contamination of ant tissues by recently ingested food, the analyses were conducted exclusively on the thorax and legs, excluding the abdomen, which contains the gut and stomach. We also analyzed items retrieved by the ants $(n=54)$. All samples were dried at $60{ }^{\circ} \mathrm{C}$ for $48 \mathrm{~h}$, ground to a fine powder, weighed in tin capsules, and stored in a dessicator until isotope measurement. For adult ants, each sample consisted of thoraces and legs to provide sufficient mass ( $c a 1 \mathrm{mg}$ ) for an accurate determination of isotope ratios. Abdomens were excluded to prevent contamination by recent food residuals. Comparisons of stable isotope values between heads and thoraces have indicated that no significant differences between these tissues exist (Tillberg et al., 2006). The collected food items were processed individually or pooled to obtain sufficient material. Isotopic analyses were performed using a mass spectrometer (Optima, Micromass, Manchester, UK) coupled to a C-N-S elemental analyser (Carlo Erba, Milan, Italy). $\delta^{13} \mathrm{C}$ values were not used because all the plants present in the area use the same mode of carbon fixation. $\delta^{15} \mathrm{~N}$ values (\%o) were expressed relative to atmospheric N2: $\delta^{15} \mathrm{~N}=[($ Rsample/Rstandard $)-1] \times 1000$, where $\mathrm{R}$ is ${ }^{15} \mathrm{~N} /{ }^{14} \mathrm{~N}$. The reference material was IAEA-N1 $(+0.4 \%$ ). One hundred replicate assays of internal laboratory standards indicate measurement errors (SD) did not exceed $\pm 0.15 \%$ for nitrogen isotopes.

\section{DATA ANALYSES}

Data were analyzed using $\mathrm{R}$ ( $\mathrm{R}$ Development Core Team, online). Seasonal variation in larval fresh weight (log-transformed) was analyzed by fitting a general linear model (GLM) using the nlme package. The month and year of excavation were considered fixed and random effects, respectively. A Bayesian approach was then used to reduce the number of non-significant levels within the explanatory variable. To that end, the 2 consecutive months with the most similar average larval weights were merged to a new unique factor level. A second model was then fitted and compared to the initial full model using the anova command 
based on the Bayesian Information Criteria (Schwarz, 1978). This operation was repeated several times until all consecutive factor levels were significant. Note that the use of standard time series analysis to detect seasonal variations would have required many more years of study.

To assess seasonal variation in foraging activity, the square-root transformed numbers of outgoing ants per day (the sum of all the hourly 10-min sessions multiplied by $6=$ sum of outgoing ants per day) were compared between months using a GLM in which the year and the colony were considered random factors (nlme package for $\mathrm{R}$ ). The number of factors within the variable Month was reduced using a Bayesian approach as explained above. Variation in the number of items collected per day was assessed with the same procedure and using the number of incoming ants carrying loads as the response variable.

In order to determine changes in the daily pattern of activity throughout the year, we first normalized the number of outgoing ants per hour. To that end, the number of outgoing ants observed during each session was divided by its maximum for that day and nest. We then tested the correlation between the average normalized numbers of outgoing ants per hour between pairs of consecutive months. In this correlation, each data point was the mean normalized activity for different nests during 2 consecutive months. If the correlation was significant, the 2 months were pooled and the average was recalculated; the operation was then repeated with subsequent consecutive time periods. Lack of a significant correlation between consecutive periods was taken to indicate a change in the daily pattern of activity.

Seasonal variation in the proportion of animal-derived items collected by foragers was assessed by fitting a linear model (LM) with the month included as a fixed factor. Variation in the proportion of the 4 main insect orders found in the diet was tested in a similar way. We used a Bonferroni procedure to reduce the $\alpha$ threshold and cope with the non-independence of these percentage data (minor groups were removed, so the sum of percentages did not equal $100 \%$, maintaining degrees of freedom in the analysis; Cisneros \& Rosenheim, 1998). A Pearson correlation test was employed to test the relationship between the average abundance of an animal order in the study area (obtained from the pitfall traps) and its average representation in the ant diet (obtained from collected items).

LMs were fitted to test seasonal variation in $A$. senilis $\delta^{15} \mathrm{~N}$ values. Finally, $A$. senilis $\delta^{15} \mathrm{~N}$ values were compared to those of the most commonly collected food items by means of GLMs in which the month of collection was included as a random factor. Values are reported as mean $\pm \mathrm{SE}$

\section{Results}

\section{LARVAL PRODUCTION AND FORAGING ACTIVITY}

Colonies of $A$. senilis collected at La Algaida contained larvae throughout the year. However, larval biomass varied greatly between months, showing a clear annual cycle with 2 main seasons. Larval biomass was relatively high in the winter-spring (December-May) and significantly lower in the summer-fall (June-November;
Figure 1a; GLM: $\left.F_{1,58}=43.60, P<0.0001\right)$. Seasonal variation in foraging activity followed a similar pattern: activity was elevated in spring (Figure 1a; March to June; $767 \pm 61$ trips $\left.\cdot \mathrm{d}^{-1}\right)$ but decreased significantly in the summer and fall (July to February: $237 \pm 22$ trips $\cdot \mathrm{d}^{-1}$; GLM: $\left.F_{1,35}=88.04, P<0.0001\right)$. However, in contrast to larval biomass, which started to increase in the winter, foraging remained very low from December to February. The number of prey retrieved per day also followed the same trend (GLM: $\left.F_{1,35}=90.50, P<0.0001\right)$. It decreased from $548 \pm 47$ items $\cdot \mathrm{d}^{-1}$ in March-June to $133 \pm 15 \mathrm{items} \cdot \mathrm{d}^{-1}$ in July-February.

The daily pattern of foraging activity also varied greatly throughout the year. Pairwise correlations between the normalized activity in consecutive months revealed 3 periods. In March and April (Figure 1b), the activity followed a unimodal pattern with a peak at midday. Similarly, the hourly activity in September, October, and November (Figure 1b) was unimodal. In contrast, in the summer (Figure 1b; May-August), ants forgo foraging during the middle of the day (14:00), giving rise to a bimodal pattern of activity with peaks at 10:00 and 17:00. The drastic changes of rhythm that occurred between the spring and summer and between the summer and fall were evidenced by the lack of correlation between normalized activity at the same hour of the day (Pearson correlation: $r=0.001, t=0.01, P=0.99$ and $r=0.25, t=0.88$, $P=0.39$, respectively).

\section{RETRIEVED ITEMS}

A total of 1074 prey items were collected and identified, $62 \pm 4 \%$ of which were of animal origin; the remainder came from plants. The proportion of animal items that ants collected varied significantly throughout the year (LM: $F_{9,27}=2.72, P=0.021$ ): a higher proportion of
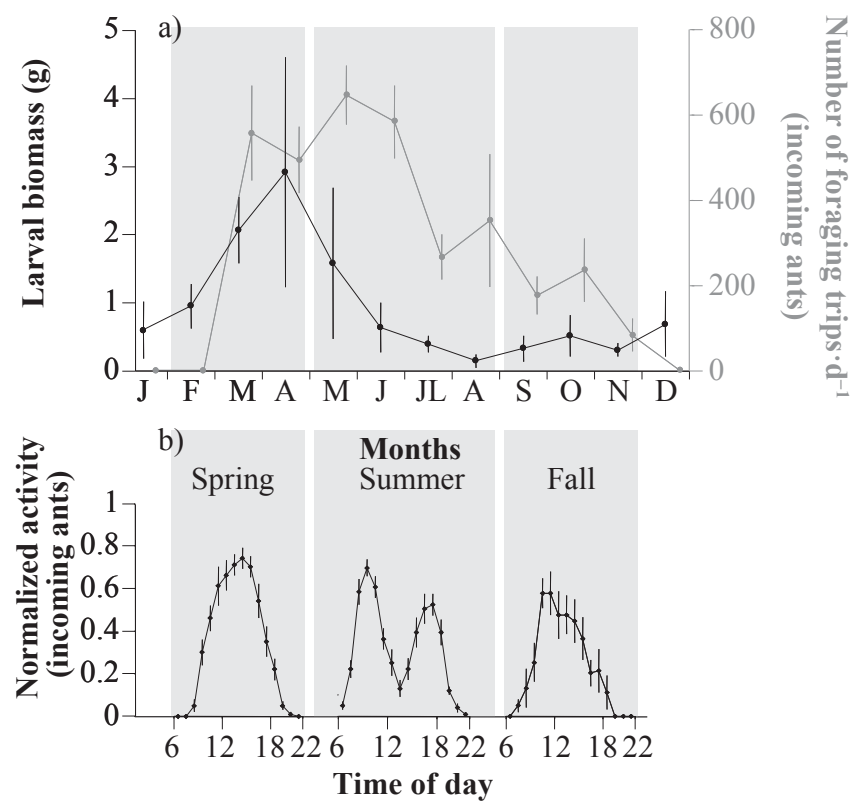

FIGURE 1. a) Circannual variation in foraging activity (dashed line) and larval biomass (solid line). b) Variation in the daily rhythm of foraging activity between spring (F, M, A), summer (M, J, JL, A), and fall (S, O, N). All values are means $\pm \mathrm{SE}$. 
animal-derived items were retrieved in February than during the rest of the year (Figure 2a; $88 \pm 4 \%$ for February versus $58 \pm 3 \%$ for the rest of the year; $t=-3.853$, $P<0.001)$. Most items were small $(<3 \mathrm{~mm})$ and were brought to the nest by individual ants (Figure 3 ). Nevertheless, a few unusually large prey items (e.g., an earthworm $45 \mathrm{~mm}$ long) were retrieved cooperatively. Overall, the number of items of a given size class found in the diet was proportional to the number of captures of that item in the pitfall traps (Pearson $\chi_{64}^{2}=72, P=0.2303$ ).

Plant items were mostly composed of fruits $(29 \%)$, flowers or petals $(25 \%)$, and seeds $(17 \%)$ of several species,
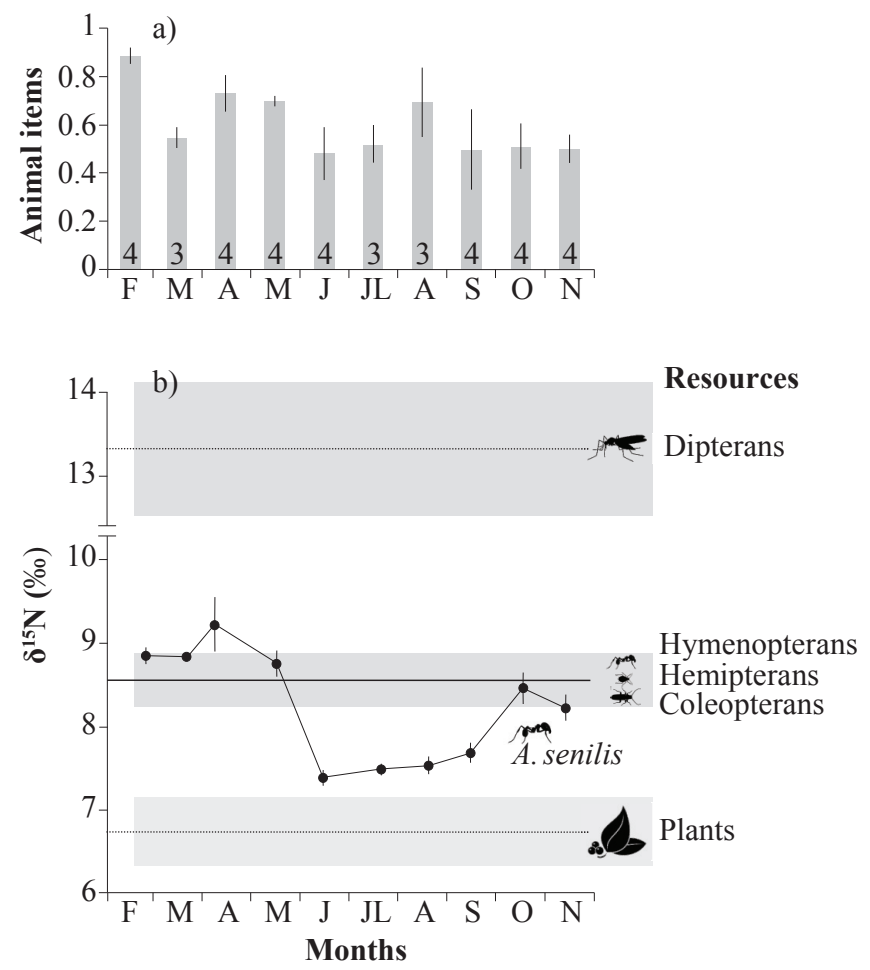

FiguRe 2. a) Proportion of animal items collected by Aphaenogaster senilis across the year. The number of nests is indicated inside each bar. b) Variation in worker nitrogen isotope values across the year. Horizontal lines and grey polygons indicate the values of the 3 main resource categories (plants, dipterans, and other insects [coleopterans, hemipterans, and hymenopterans]). Nitrogen isotope values were corrected using a discrimination factor of 3\%o (Feldhaar, Gebauer \& Blúthgen, 2010). All values are means $\pm \mathrm{SE}$.

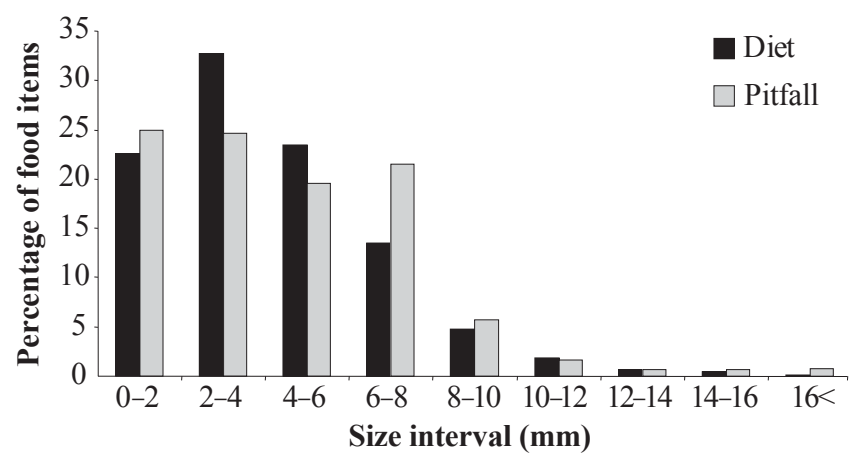

FIGURE 3. Percentage of animal-derived items of different size classes $(\mathrm{mm})$ in the ant diet (black bars, $n=884$ ) versus pitfall traps (grey bars, $n=4929)$. including Phyllirea angustifolia, Pistacea lentiscus, and Arum italicum (EA2). Twenty-four invertebrate orders were represented in the animal-derived items. The majority were dipterans (mostly mosquitoes), hemipterans (mostly aphids), coleopterans, and hymenopterans. The proportion of dipterans, hemipterans, and coleopterans did not vary significantly across the year $\left(23 \pm 8 \%\right.$, LM: $F_{9,27}=2.05$, $P=0.05 ; 14 \pm 4 \%$, LM: $F_{9,27}=2.24, P=0.07 ; 10 \pm 2 \%$, LM: $F_{9,27}=0.45, P=0.89$, respectively; 0.015 after Bonferroni correction; Figure 4). The proportion of hymenopterans (mostly other ants) was significantly higher in June-July $(74 \pm 30 \%)$ than during the rest of year $(14 \pm 2 \%$; LM: $\left.F_{1,35}=72.2, P<0.001\right)$. Although many retrieved animal items were dead or dying when collected, aphids, mosquitoes, small insect larvae, and some small coleopterans were clearly captured alive. On some occasions, even large living animals (caterpillars, earthworms, and large coleopterans) were transported cooperatively.

There was a significant correlation between the abundance of an animal order in the area of study and its representation in the $A$. senilis diet (Figure 4 and EA3; Pearson correlation: $\left.t=6.19, P<0.0001, R^{2}=0.62\right)$. The hemipterans were an outlier, but mostly because pitfall traps are not suited for estimating their abundance. Removing them from the analysis increased $R^{2}$ to $0.74(t=8.54$, $P<0.0001)$.

\section{ISOTOPIC ANALYSES}

The $\delta^{15} \mathrm{~N}$ values of $A$. senilis workers varied significantly throughout the year (LM: $F_{1,20}=19.6, P<0.0001$ ), with a clear distinction seen between seasons (Figure $2 b$ ). Hence, $\delta^{15} \mathrm{~N}$ values decreased significantly between the spring (February-May: $8.92 \pm 0.1$ ) and the summer (June-September: $7.52 \pm 0.05 ; t_{\text {(spring-summer) }}=-12.56$, $P<0.0001)$. In the fall (October-November), $\delta^{15} \mathrm{~N}$ values increased again to a value intermediate to those of the summer and spring $\left(8.34 \pm 0.12 ; t_{\text {(spring-fall })}=-4.23, P=0.0002\right.$ and $t_{\text {(summer-fall) }}=6.25, P<0.0001$ ).

Isotopic analyses of $A$. senilis' main food resources indicated that coleopterans, hymenopterans, and hemipterans formed a homogenous group with low $\delta^{15} \mathrm{~N}$ values. Their $\delta^{15} \mathrm{~N}$ values (Figure 2b: $5.56 \pm 0.35$ ) were significantly higher than those of plants $(3.74 \pm 0.46 ; t=8.08$, $P<0.0001)$ and significantly lower than those of dipterans $(10.37 \pm 0.89 ; t=-4.99, P<0.0001)$. Aphaenogaster senilis $\delta^{15} \mathrm{~N}$ values were in-between those of granivores and dipterans $\left(t_{(A \text {. senilis-herbivores })}=-5.52, P<0.0001\right.$; $\left.t_{(A . \text { senilis-dipterans })}=2.23, P=0.029\right)$.

\section{Discussion}

In this study, we have shown an important plasticity in A. senilis foraging rate, daily activity patterns, and diet in southern Spain. Results show that colonies are active almost throughout the year, but larval biomass production and foraging activity occur primarily in the spring. The daily pattern of activity changes greatly between seasons, probably as a consequence of temperature constraints. By combining observation of retrieved food items with isotopic analyses, we found that colonies are omnivorous, feeding on a wide 
array of food resources, including insects (dead and alive) and plant material. Direct observation of retrieved food

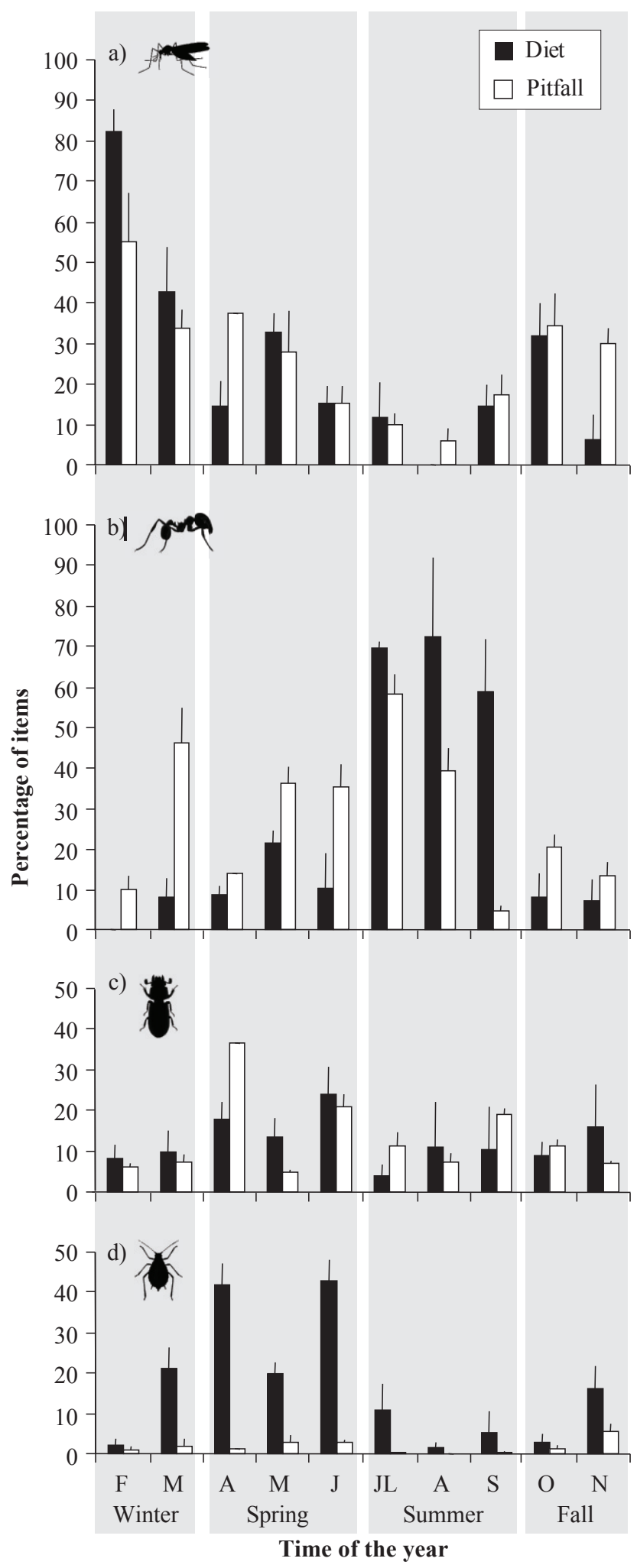

FIGURE 4. Percentage (mean \pm SE) of the 4 most important insect taxonomic groups [Diptera (a), Formicidae (b), Coleoptera (c), and Hemiptera (d)] collected across the year by ants (black bars) versus captured in the pitfall traps (white bars). items did not reveal a major shift in $A$. senilis alimentation throughout the year. However, isotopic analyses of workers suggested reduced consumption of animal protein in the summer.

Like most animal species in temperate and Mediterranean habitats (Wyndham, 1986; Levey \& Stiles, 1992), A. senilis displays a clear annual cycle of brood growth and foraging activity. Larvae mostly develop in the spring, and there is a major corresponding increase in foraging activity. Although there is an evident relationship between colony-level food intake and larval growth, the causal chain relating the 2 phenomena may be mediated by other factors. For example, larval growth and worker foraging behaviour may be constrained by the same environmental variables, such as temperature and humidity (e.g., Cerdá, Retana \& Cros, 1998b; Cerdá, Retana \& Manzaneda, 1998; Kipyatkov et al., 2004; Kipyatkov, Lopatina \& Imamgaliev, 2005; Boulay et al., 2009; Cerdá et al., 2012; van Oudenhove et al., 2012). In particular, cold winter and hot summer temperatures may respectively limit foraging and larval growth. In contrast, spring weather conditions may stimulate foraging and increase food retrieval, thus favouring larval growth. Another factor that may potentially increase foraging rate is the colony members' state of hunger. Larval hunger state is known to stimulate worker foraging in some ant species (Brian \& Abbott, 1977; Dussutour \& Simpson, 2009). It is therefore possible that the progressive increase in the number of small larvae in FebruaryMarch triggers adult foraging behaviour. However, in July, the number of incoming, loaded $A$. senilis ants per day was still relatively high, while larval biomass was already close to zero, suggesting larval presence was not the only factor stimulating foraging. The hunger state of young adult workers and sexuals may also affect ant foraging decisions, as suggested by Cassill and Tschinkel (1999) and Judd (2005). Finally, demography and age-dependent division of labour may also influence seasonal variation in the foraging rate: in the spring, colonies are composed of relatively old workers that were born before the winter and that may be more prone to forage than younger ones (Robinson, 1992; Muscedere \& Traniello, 2012).

We found a major shift in the daily pattern of activity of $A$. senilis between the spring, summer, and fall. While colonies were mostly active midday in the spring and fall, activity decreased drastically during these hours in the summer, probably because ants sought to escape extremely hot ground temperatures. Ground temperature in the study area may approach $70{ }^{\circ} \mathrm{C}$ during these hours, which is well above the lethal limit for $A$. senilis (critical thermal limit: $46{ }^{\circ} \mathrm{C}$; lethal temperature: $50{ }^{\circ} \mathrm{C}$; Cerdá et al., 1998). In Mediterranean habitats, elevated ground temperature has been widely reported to constrain ant activity (Cros, Cerdá \& Retana, 1997; van Oudenhove et al., 2011), and many ant species exhibit a shift in their daily rhythm between the hot and cold seasons (Amor et al., 2011; van Oudenhove et al., 2012). In addition to increasing the risk of mortality, a hot ground surface may interfere with ant chemical communication by reducing the stability of trail markers and 
preventing nestmate recruitment (Ruano, Tinaut \& Soler, 2000; van Oudenhove et al., 2012).

Observations of retrieved items suggest $A$. senilis is an omnivorous species with a low feeding specificity. Most food items were sufficiently small to be transported by individual ants. However, on rare occasions, the ants retrieved extremely large prey, which required the cooperation of several individuals. Given that most available prey items are small, the value of such rare, large prey to the colony is probably high. Cerdá et al. (1998) found that the largest $12 \%$ of prey retrieved by $A$. senilis represented up to $72 \%$ of transported biomass. The proportion of the various insect taxa in the $A$. senilis diet was well predicted by their abundance in the area of study as measured with pitfall traps. We observed 2 important and consecutive resource categories in A. senilis: Dipterans in winter and spring followed by Formicidae in summer, especially Mesor sp. This finding highlights the relative opportunism of $A$. senilis and its capacity to use a large array of prey. Aphids represented an outlier in the relationship between insect abundance in nature and their occurrence in the $A$. senilis diet. This is because aphids are sessile animals that are not well sampled using pitfall traps. Like many ants in Mediterranean habitats (Fellers \& Fellers, 1982; Retana, Cerdá \& Espadaler, 1991; Angulo, Caut \& Cerdá, 2012), A. senilis behaved as a scavenger, retrieving dead or moribund prey. It also predated on a number of living prey, including caterpillars, coleopterans, and numerous aphids. However, in contrast to many species, such as Tapinoma and Lasius, that may be both mutualistic and predaceous, $A$. senilis does not tend aphids in order to get liquid honeydew (Bristow, 1984; Matsuura \& Yashiro, 2006). Therefore, A. senilis may indirectly have a net positive effect on plants by reducing herbivory.

In addition to insects, $A$. senilis retrieved relatively large numbers of seeds and fruits from several plant species. Previous studies have shown that in the south of the Iberian Peninsula, A. senilis and the congeneric species A. iberica contribute disproportionately to the dispersal of various myrmecochores (Espadaler \& Gómez, 1997; Boulay et al., 2005; 2007a; Bas, Oliveras \& Gómez, 2009). Similarly, the genus Aphaenogaster is a keystone disperser of myrmecochores in North American temperate woodlands (Ness, Morin \& Giladi, 2009). However, none of the diaspores removed by $A$. senilis at our study site had an elaiosome. Phyllirea angustifolia, Pistacea lentiscus, and Arum italicum were among the most frequently exploited plant species. The first 2 are bird-dispersed, while the last has no known legitimate disperser. Our results thus confirm the potential importance of $A$. senilis in the redistribution of numerous seeds adapted to other modes of dispersal (Traveset, 1994; Hulme, 1997). Further studies should investigate the survival and germination rates of seeds transported by Aphaenogaster.

Direct observations of the food items retrieved showed a significant difference in the proportion of animal-derived items between February and the rest of the year. However, in February, A. senilis has a very low activity level, and the result for this month should be interpreted with caution. In contrast, ant $\delta^{15} \mathrm{~N}$ values decreased between June and September, suggesting an important dietary shift towards plant-derived materials. Nevertheless, the important shift in prey items during summer between dipterans and Formicidae could partly explain this decrease in $\delta^{15} \mathrm{~N}$ (nitrogen isotopic values of Formicidae were lower than dipterans, Figure 2b). The apparent incongruity between the isotopic and observational data may be due to high variability between nests for the 2 types of data. Moreover, although the number of retrieved fruits and seeds did not change, their dietary contribution in terms of biomass may be much higher in the summer than in the spring. Large fruits, like those of A. italicum, $P$. angustifolia, and $P$. lentiscus, were mostly collected from June to November. The consumption of plant liquids by $A$. senilis is very rare and is unlikely to account for the different isotopic and observational data. In general, ant larvae are the major consumers of proteins, while adult workers rely on carbohydrates (Vinson, 1968). The reduction of larval biomass between the spring and the summer could therefore result in a reduced need for insect prey and therefore harvesting patterns that favour plant-derived carbohydrates. Such seasonal changes in food preference have been reported in Solenopsis invicta (Stein, Thorvilson \& Johnson, 1990), Pheidole ceres (Judd, 2005), and Linepithema humile (Abril, Oliveras \& Gómez, 2007), to name a few examples.

Our results exemplify the ability of isotopic analyses to capture differences in ant diet that are difficult to observe from analysis of retrieved items alone. More generally, animal diets determined by foraging observations alone are sometimes difficult to interpret because they only provide information about what an animal has eaten during a recent, brief time window. Stable isotopes offer advantages over these methods by providing time-integrated information on assimilated foods (Boutton, Arshad \& Tieszen, 1983). However, one difficulty in using stable isotope analysis to evaluate resource incorporation is that consumer metabolic processes may discriminate between different isotopes, causing the isotopic ratio of the consumer to differ slightly from that of the food resource. This difference is called the discrimination factor. Using controlled feeding experiments on Camponotus floridanus, Feldhaar, Gebauer, and Blúthgen (2010) found a discrimination factor for isotopic nitrogen of about 3\%. This level of enrichment is consistent with the difference between the $A$. senilis isotopic values we observed in the field and values we found in their diet (Figure 2c). However, studies to determine the turnover rate in ants (the time it takes for the isotope to be assimilated into the consumer's tissue) are lacking. It is important to determine whether the isotope signature of workers represents their most recent diet or also reflects their larval food.

Overall, our results suggest that the foraging rate of A. senilis varies throughout the year in accordance with larval biomass and environmental constraints. Foragers appeared to be opportunistic and transported a large variety of food items to the nest, although food selection may occur within the colony as a function of the internal demand. This apparent plasticity in foraging activity and resource use may be key to the ecological success of this otherwise behaviourally subordinate species. Further studies are needed to 
better understand ant feeding ecology in natural conditions in relation to colony life cycle. Observational data and isotopic analyses are complementary tools that together can provide a finely tuned picture of food selection at different scales.

\section{Acknowledgements}

We are grateful to L. Michel and G. Lepoint for technical help with the mass spectrometer. We wish to thank J. PearceDuvet for improvement of the English. This work was funded by Ministerio de Ciencia e Innovación (project CONSOLIDERMONTES CSD2008-00040), MICINN and Fondo Europeo de Desarrollo Regiona (projects CGL2009-12472 to RB and CGL2009-09690 to XC), and the Consejo Superior de Investigaciones Cientificas (JAE postdoctoral contract to Stephane Caut). The authors thank the authorities of Doñana Natural Park for granting them permission to conduct research in the park.

\section{Literature cited}

Abril, S., J. Oliveras \& C. Gómez, 2007. Foraging activity and dietary spectrum of the Argentine Ant (Hymenoptera: Formicidae) in invaded natural areas of Northeast Iberian Península. Environmental Entomology, 36: 1167-1173.

Amor, F., P. Ortega, M. J. Jowers, X. Cerdá, J. Billen, A. Lenoir $\&$ R. Boulay, 2011. The evolution of worker-queen polymorphism in Cataglyphis ants: Interplay between natural and kin selection. Behavioural Ecology and Sociobiology, 65: $1473-1482$.

Angulo, E., S. Caut \& X. Cerdá, 2011. Scavenging in Mediterranean ecosystems: Effect of the invasive Argentine ant. Biological Invasions, 13: 1183-1194.

Bas, J. M., J. Oliveras \& C. Gómez, 2009. Myrmecochory and short-term seed fate in Rhamnus alaternus: Ant species and seed characteristics. Acta Oecologia, 35: 380-384.

Blüthgen, N., G. Gebauer \& K. Fiedler, 2003. Disentangling a rainforest food web using stable isotopes: Dietary diversity in a species-rich ant community. Oecologia, 137: 426-435.

Boulay, R., J. M. Fedriani, A. J. Manzaneda \& X. Cerdá, 2005. Indirect effects of alternative food resources in an ant-plant interaction. Oecologia, 144: 72-79.

Boulay, R., F. Carro, R. Soriguer \& X. Cerdá, 2007a. Synchrony between fruit maturation and effective dispersers' foraging activity increases seed protection against seed predators. Proceedings of the Royal Society B, 274: 2515-2522.

Boulay, R., A. Hefetz, X. Cerdá, S. Devers, W. Francke, R. Twele $\&$ A. Lenoir, 2007b. Production of sexuals in a fission-performing ant: Dual effects of queen pheromones and colony size. Behavioral Ecology and Sociobiology, 61: 1531-1541.

Boulay, R., X. Cerdá, A. Fertin, K. Ichinose \& A. Lenoir, 2009. Brood development into sexual females depends on the presence of a queen but not on temperature in an ant dispersing by colony fission, Aphaenogaster senilis. Ecological Entomology, 34: 595-602.

Boutton, T. W., M. A. Arshad \& L. L. Tieszen, 1983. Stable isotope analysis of termite food-habits in East-African grasslands. Oecologia, 59: 1-6.

Briese, D. T. \& B. J. Macauley, 1980. Temporal structure of an ant community in semi-arid Australia. Australian Journal of Ecology, 5: 121-134.
Brian, M. V. \& A. Abbott, 1977. The control of food flow in a society of the ant Myrmica rubra L. Animal Behaviour, 25: 1047-1055.

Bristow, C. M., 1984. Differential benefits from ant attendance to two species of Homoptera on New York ironweed. Journal of Animal Ecology, 53: 715-726.

Carroll, C. R. \& D. H. Janzen, 1973. Ecology of foraging by ants. Annual Review of Ecology, Evolution, and Systematics, 4: $231-257$

Cassill, D. L. \& W. R. Tschinkel, 1999. Regulation of diet in the fire ant, Solenopsis invicta. Journal of Insect Behavior, 12: $307-328$.

Caut, S., E. Angulo \& F. Courchamp, 2008. Caution on isotopic model use for analyses of consumer diet. Canadian Journal of Zoology, 86: 438-445.

Caut, S., E. Angulo \& F. Courchamp, 2009. Variation in discrimination factors $\left(\Delta^{15} \mathrm{~N}\right.$ and $\left.\Delta^{13} \mathrm{C}\right)$ : The effect of diet isotopic values and applications for diet reconstruction. Journal of Applied Ecology, 46: 443-453.

Cerdá, X., E. Angulo, R. Boulay \& A. Lenoir, 2009. Individual and collective foraging decisions: a field study of worker recruitment in the gypsy ant Aphaenogaster senilis. Behavioral Ecology and Sociobiology, 63: 551-562.

Cerdá, X., J. Retana \& S. Cros, 1998a. Prey size reverses the outcome of interference interactions of scavenger ants. Oikos, 81: 99-110.

Cerdá, X., J. Retana \& S. Cros, 1998b. Critical thermal limits in Mediterranean ant species: Trade-off between mortality risk and foraging performance. Functional Ecology, 12: 45-55.

Cerdá, X., J. Retana \& A. Manzaneda, 1998. The role of competition by dominants and temperature in the foraging of subordinate species in Mediterranean ant communities. Oecologia, 117: 404-412.

Cerdá, X., E. Angulo, S. Caut \& F. Courchamp, 2012. Ant community structure on a small Pacific island: Only one native species living with the invaders. Biological Invasions, 14: $323-339$.

Chong, K. \& C. Lee, 2009. Influences of temperature, relative humidity and light intensity on the foraging activity of field populations of the longlegged ant, Anoplolepis gracilipes (Hymenoptera: Formicidae). Sociobiology, 54: 531-539.

Cisneros, J. J. \& J. A. Rosenheim, 1998. Changes in the foraging behavior, within-plant vertical distribution, and microhabitat selection of a generalist insect predator. Environmental Entomology, 27: 949-957.

Cook, S. C., M. D. Eubanks, R. E. Gold \& S. T. Behmer, 2011. Seasonality directs contrasting food collection behavior and nutrient regulation strategies in ants. PlosOne, 6: e25407.

Cros, S., X. Cerdá \& J. Retana, 1997. Spatial and temporal variations leading to contrasting activity patterns in Mediterranean ant communities. Écoscience, 4: 269-278.

Dejean, A., B. Schatz, J. Orivel \& G. Beugnon, 1999. Feeding preferences in African ponerine ants: A cafeteria experiment Sociobiology, 34: 545- 554.

Dussutour, A. \& S. J. Simpson, 2009. Communal nutrition in ants Current Biology, 19: 740-744.

Edwards, J. P. \& L. Abraham, 1990. Changes in food selection by workers of the Pharaoh's ant, Monomorium pharaonis. Medical and Veterinary Entomology, 4: 205-211.

Espadaler, X. \& C. Gómez, 1997. Soil surface searching and transport of Euphorbia characias seeds by ants. Acta Oecologia, 18: 39-46. 
Feldhaar, H., G. Gebauer \& N. Blúthgen, 2010. Stable isotopes: Past and future in exposing secrets of ant nutrition (Hymenoptera: Formicidae). Myrmecological News, 13: 3-13.

Fellers, G. M. \& J. H. Fellers, 1982. Scavenging rates of invertebrates in an eastern deciduous forest. American Midland Naturalist Journal, 107: 389-392.

Gibb, H. \& S. A. Cunningham, 2011. Habitat contrasts reveal a shift in the trophic position of ant assemblages. Journal of Animal Ecology, 80: 119-127.

Gomez, K. \& X. Espadaler, online. hormigas.org. Online [URL] http://www.hormigas.org/xEspecies/Aphaenogaster\%20senilis. htm (Accessed on 3 July 2012).

Hölldobler, B., 1982. Communication, raiding behavior and prey storage in Cerapachys (Hymenoptera: Formicidae). Psyche, 89: 3-23.

Hölldobler, B. \& E. O. Wilson, 1990. The Ants. Harvard University Press, Cambridge, Massachusetts.

Hulme, P., 1997. Post-dispersal seed predation and the establishment of vertebrate dispersed plants in Mediterranean scrublands. Oecologia, 111: 91-98.

Judd, T. M., 2005. The effects of water, season, and colony composition on foraging preferences of Pheidole ceres [Hymenoptera: Formicidae]. Journal of Insect Behavior, 18: 781-803

Kay, A., 2002. Applying optimal foraging theory to assess nutrient availability ratios for ants. Ecology, 83: 1935-1944.

Kay, A., 2004. The relative availabilities of complementary resources affect the feeding preferences of ant colonies. Behavioral Ecology, 15: 63-70.

Kelly, J. F., 2000. Stable isotopes of carbon and nitrogen in the study of avian and mammalian trophic ecology. Canadian Journal of Zoology, 78: 1-27.

Kipyatkov, V., E. Lopatina \& A. A. Imamgaliev, 2005. Duration and thermal reaction norms of development are significantly different in winter and summer brood pupae of the ants Myrmica rubra Linnaeus, 1758 and M. ruginodis Nylander, 1846 (Hymenoptera: Formicidae). Myrmecologische Nachrichten, 7: 69-76.

Kipyatkov, V. E., E. B. Lopatina, A. A. Imamgaliev \& L. A. Shirokova, 2004. Effect of temperature on rearing of the first brood by the founder females of the ant Lasius niger (Hymenoptera, Formicidae): Latitude-dependent variability of the response norm. Journal of Evolutionary Biochemistry and Physiology, 40: 165-175.

Levey, D. J. \& F. G. Stiles, 1992. Evolutionary precursors of longdistance migration resource availability and movement patterns in neotropical landbirds. American Naturalist, 140: 447-476.

Matsuura, K. \& T. Yashiro, 2006. Aphid egg protection by ants: A novel aspect of the mutualism between the tree-feeding aphid Stomaphis hirukawai and its attendant ant Lasius productus. Naturwissenschaften, 93: 506-510.

Menke, S. B., A. V. Suarez, C. V. Tillberg, C. T. Chou \& D. A. Holway, 2010. Trophic ecology of the invasive Argentine ant: Spatio-temporal variation in resource assimilation and isotopic enrichment. Oecologia, 164: 763-771.

Mooney, K. A. \& C. V. Tillberg, 2005. Temporal and spatial variation to ant omnivory in pine forests. Ecology, 86: 1225-1235.

Monnin, T., X. Espadaler, A. Lenoir \& C. Peeters, 2013. Guide des fourmis de France. Éditions Belin.

Muscedere, M. L. \& J. F. A. Traniello, 2011. Division of labor in the hyperdiverse ant genus Pheidole is associated with distinct subcaste and age-related patterns of worker brain organization. PlosOne, 7: e31618.
Narendra, A., S. F. Reid \& J. M. Hemmi, 2010. The twilight zone: Ambient light levels trigger activity in primitive ants. Proceedings of the Royal Society B, 277: 1531-1538.

Ness, J. H., D. F. Morin \& I. Giladi, 2009. Uncommon specialization in a mutualism between a temperate herbaceous plant guild and an ant: Are Aphaenogaster ants keystone mutualists? Oikos, 118: 1793-1804

Orr, M. R. \& S. H. Seike, 1998. Parasitoids deter foraging by Argentine ants (Linepithema humile) in their native habitat in Brazil. Oecologia, 117: 420-425.

Post, D. M., 2002. Using stable isotopes to estimate trophic position: Models, methods, and assumptions. Ecology, 83: 703-718.

R Development Core Team. R: A Language and Environment for Statistical Computing. R Foundation for Statistical Computing, Vienna. Online [URL] http://www.R-project.org/ (Accessed on 10 October 2012)

Retana, J., X. Cerdá \& X. Espadaler, 1991. Arthropod corpses in a temperate grassland: A limited supply? Holarctic Ecology, 14: 63-67.

Robinson, G. E., 1992. Regulation of division of labor in insect societies. Annual Review of Entomology, 37: 637-665.

Ruano, F., A. Tinaut \& J. J. Soler, 2000. High surface temperatures select for individual foraging in ants. Behaviour Ecology, 11: 396-404.

Schwarz, G. E., 1978. Estimating the dimension of a model. Annals of Statistics, 6: 461-464.

Smith, C. R. \& A. V. Suarez, 2010. The trophic ecology of castes in harvester ant colonies. Functional Ecology, 24: 122-130.

Smith, C. R., K. E. Anderson, C. V. Tillberg, J. Gadau \& A. V. Suarez, 2008. Caste determination in a polymorphic social insect: Nutritional, social, and genetic factors. American Naturalist, 172: 497-507.

Stein, M. B., H. G. Thorvilson \& J. W. Johnson, 1990. Seasonal changes in bait preference by red imported fire ant, Solenopsis invicta (Hymenoptera, Formicidae). Florida Entomologist, 73: $117-123$.

Stephens, D. W., J. S. Brown \& R. C. Ydenberg, 2007. Foraging: Behavior and Ecology. University of Chicago Press, Chicago, Illinois.

Stephens, D. W. \& J. R. Krebs, 1986. Foraging Theory. Princeton University Press, Princeton, New Jersey.

Tillberg, C. V., D. P. McCarthy, A. G. Dolezal \& A. V. Suarez, 2006. Measuring the trophic ecology of ants using stable isotopes. Insectes Sociaux, 53: 65-69.

Traveset, A., 1994. Cumulative effects on the reproductive output of Pistacia terebinthus (Anacardiaceae). Oikos, 71: 152-162.

van Oudenhove, L., E. Billoir, R. Boulay, C. Bernstein \& X. Cerdá, 2011. High temperatures affect trail efficiency through pheromone decay in ants. Naturwissenschaften, 98: 1009-1017.

van Oudenhove, L., R. Boulay, A. Lenoir, C. Bernstein \& X. Cerdá, 2012. Substrate temperature constrains recruitment and trail following behavior in ants. Journal of Chemical Ecology, 38: 802-809.

Vinson, S. B., 1968. Distribution of an oil, carbohydrate and protein food source to members of imported fire ant colony. Journal of Economic Entomology, 61: 712-714.

Wyndham, E., 1986. Length of birds' breeding seasons. American Naturalist, 128: 155-164. 